\title{
Research on the Guiding Effect of Horse Racing Events on the Talent Training of Horse Racing Specialty in Colleges and Universities
}

\author{
Shuang Zhang ${ }^{\mathrm{a}}$, Yaonan $\mathrm{Li}^{\mathrm{b}}{ }^{\text {* }}$ \\ Wuhan Business University, Wuhan 430056, China \\ a61758827@qq.com, *, b tiredhiker@hotmail.com
}

Keywords: Horse racing event, horse racing specialty, talent training.

\begin{abstract}
This paper carries on research on the demand for talents of horse racing events in China by means of literature data method, investigation method, field survey method and expert interview method. The results show that horse racing events in China present the current situation of high event density, advanced technology and shortage of competition personnel. In order to promote the further development of horse industry, the colleges and universities should take events as the guidance of the training of horse racing talents; increase the training of students' organizing ability in horse racing events and referees' ability, and provide high-quality and versatile horse racing talents for the development of horse industry.
\end{abstract}

\section{Introduction}

The development of horse racing events is an important way to test the sports ability of horses, the horsemanship level of jockey, and the training level of trainer, which is the only way to enhance the value of horses as well. At present, the horse racing events in Hong Kong and Macao develop frequently and stably in China, with widespread influence, the opening of the equestrian clubs and the development of the horse racing events in the Chinese mainland have also been increasing year by year, however, the organization and implementation of the horse racing events in the Chinese mainland are lacking in professional and stable talent pool. In order to solve the problem of talent shortage, some colleges and universities have already opened the horse racing specialty in our country. But because the opening of horse racing specialty is late and the positioning accuracy of the market demand are not high, cause the training of horse racing professionals to divorce from market demands, many graduates are very difficult to quickly enter the working state. In order to better promote the development of horse racing career, train the talents of horse racing events with high quality and suitable for the development of market demand, the training of horse racing professionals in colleges and universities should take the events as the center, the events as the guidance to establish a scientific and perfect human training system, focus on training students' comprehensive abilities, especially the organization and implementation abilities of horse racing events. For this reason, through the investigation and research of the domestic horse racing events and graduates in horse racing specialty at present, this research analyzes the training program of horse racing talents and puts forward feasible training suggestions of horse racing talents which oriented horse racing events.

\section{The Present Situation of Horse Racing Events}

\subsection{Normalization of the Events}

In recent years, horse racing events present normalization trend in domestic development, various equestrian clubs hold fixed number of events every year, there are a large number of events among various clubs, the China Horse Industry Association and equestrian association every year. For example, the events officially reported by Chinese equestrian association in 2017, the endurance race is 6 , the speed racing is 9 , the barrel racing is 6 , the polo is 1 , etc. There are more than 200 regular events voluntarily held by various race courses. And with the development of the horse industry, the annually held events of the horse racing events are increasing year by year. The number of events and 
the phenomenon of the increasing racecourses show that the horse racing event has been in a normalized development.

\subsection{Information of the Events}

Information technology is widely used in various fields, and horse industry is no exception. the pre-competition registration system of horse racing event, automation generation and output of event program, arrangement of event and handling of event score, generation and archive of the event result, instant announcement of final result of the event, instant statistical analysis and announcement of comprehensive score, the score and class of the horse, the weight of horse, judgment and output of finishing point ranking and so on all adopt the information operation. The information of the event can improve the execution efficiency of the events, reduce communication cost, improve the consistency of information, and facilitate the storage and call of event data.

\subsection{Internationalization of Events}

Horse racing industry is an international industry, foreign horse racing industry developed more than the domestic, such as Britain, the United States, France, Japan, the domestic horse racing industry is still in infancy and rapid development stage, there are shortages of various talents, and must learn from the horse industry from developed countries. Many domestic equestrian clubs employ foreign trainers and foreign jockeys, there are also international jockeys and foreign horses participating in the races in large-scale events, the horse racing events present distinctly international characteristics. At present, the foreign referee teams appear in many foreign events will, and even many events are completed or dominated by the foreign referee teams, which also reflects the internationalization of horse racing events.

\subsection{Large Amounts of the Needs of the Events Personnel}

The number of participants in one game is 40 to 50 in the speed race of the horse racing events. They include personnel which lead horse, site management personnel, saddled personnel, saddler delivery personnel, weighed personnel, brake personnel, supervisory personnel, endpoint timekeeper, endpoint recorder, the event organization personnel, other event coordinators, etc. The number of participants is enormous. The organization of the event is a time-consuming, capital-consuming, labor-consuming and material-consuming process, the most difficult of which is the organization of the event relevant personnel. At home, referees at large events are generally selected by the equestrian association, because our country equestrian referee reserve quantity is less, so when the equestrian association seconding personnel only send the chief referee in key positions, there are serious shortages for the assistant referees and related personnel of position, which completely can't meet the needs of the horse racing events for personnel.

\section{The Present Situation of Talent Training Horse Racing Specialty in Colleges and Universities}

\subsection{Broad Course System}

At present, colleges and universities that open horse racing talents training are led by Wuhan Business University, after several years of development, the college horse racing specialty has developed relatively mature. The trainings of horse racing specialty students in Wuhan Business University are mainly embodied in the skill and application forms. It was found that interviews with students and students who have already worked, there is a broad status in the college course system, the courses offered are extensive, there is no specific job classification course system setting for the horse racing industry.

\subsection{Superficial Course Content}

Through the test of skill ability of students and graduates, it is found that the teaching content of college courses is not deep enough. The most obvious thing is that the teaching of riding course only requires students to master basic walking, strolling and jumping, and have the basic ability to control the horses. The lack of depth of course content can cause students ' basic skills to be low, it is easy to make students lose confidence and feel frustration in external competition. After students going to the 
society, they need to further study, waste a lot of time, and it is not good for students to enter work quickly.

\subsection{Poor Communication Skills in Foreign Languages}

The student source of horse racing specialty is the students with sports talents, there are generally poor foreign language situation for students with sports talents. Non-sports students also have dumb foreign language, the domestic status need to specifically make adjustments in the training program, increase the training strength of foreign language for horse racing professionals. Only improving the communication ability of the foreign language can communicate with international friends in the horse racing events, so facilitate the smooth development of horse racing events work.

\subsection{Lack of Practice Conditions}

Skill trainings of students majoring in horse racing tend to lack the necessary practice conditions, for example, there are only ten horses in the campus racecourse of Wuhan Business University, and all are retired racing horses, there are only two guiding circles in the field. This kind of practice condition is completely unable to meet the practice course demand for three or four hundred students. Some colleges and universities take the university-enterprise cooperation form to train the students' skills, but geographical position of equestrian club generally near the suburbs, while school is located in the downtown, so the economic cost and time cost of students' each practice will increase, it is not very proper for school education. The lack of practice conditions is a common problem in all universities that open horse racing specialty.

\section{Improvement Direction of Talent Training of Horse Racing Professionals in Colleges and Universities}

\subsection{The Horse Racing Events as Guidance}

The event is the core power of the horse industry development. The talents training of horse racing in colleges and universities should be guided by the horse racing events, and focusing on training students' ability to adapt to the events positions. Trying to avoid generalization and dabble in the talent training. The formulation of talent training program should reflect the core value of the events and pay attention to the development and application of the course. At the same time, setting up the talent training program systems which orient the job demand, and trains the diversified development talents which take the events as main.

\subsection{Pay Attention to the Training of Practice Ability}

At present, the disconnection situation between theory and practice permeates in talent training in colleges and universities. This situation can make students' understand theory more difficult, and it is not conducive for students to learn theoretical knowledge by heart. If change teaching mode, the practice as the center, assist theory teaching, studying in doing, which can not only make students further understand the theoretical knowledge, meanwhile can improve the students' practice ability, deepen the memory of knowledge. Horse racing industry belongs to the practical industry, whether the stable job, veterinarian job, farrier work or event work, all need relevant personnel have strong practice ability, therefore, talents training of horse racing should pay attention to the training of practice ability.

\subsection{Pay Attention to the Events Organization and Training of Practice Ability}

School education should be go deep into enterprise practice, theory and practice should be closely integrated. Because the domestic horse racing events are highly dense and seriously lack event personnel, therefore, the school education and the holding of horse racing events should be organically integrated. In this way, the lack of personnel during the club events is solved, and the students' extracurricular practice problems are solved, students can organize and implement specific events in the practice course, and teachers guide them, this way can help students to rapidly grow and benefit students' further development.

\subsection{Strengthen the Information Technology and Foreign Language Education}

Pre-match registration system in race events, automatic generation and output of race program, arrangement of tournaments and tournament scores, generation and archiving of event tickets, instant 
announcement of event final grade information, real-time statistical analysis of comprehensive scores and Published, the horse's score and class, the horse's negative pounds, the final position of the judge and the output and so on are involved in information technology operations, and therefore should strengthen the information technology education of students, focusing on training students practical ability. In view of the horse racing industry is an international industry; students should be strengthened in foreign language proficiency, especially oral education.

The pre-competition registration system of horse racing event, automatic generation and output of events program, arrangement of events and handling of race results, generation and archive of event results, instant announcement of final result of the event, instant statistical analysis and announcement of comprehensive score, the score and class of the horse, the weight of horse, judgment and output of finishing point ranking and so on all involve the information operation, therefore, the information technology education for students should be strengthened, focus on cultivating students' practice ability. Considering the horse racing industry belongs to the international industry, students' foreign language level should be strengthened and especially the education of oral ability.

\section{Conclusion}

5.1 The present situations of horse racing events are the normalization, information, internationalization of events and a great quantity of demand for event personnel. There are broad course system, superficial course content, poor foreign language communication skills and lack of practice conditions and so on in the training of college horse racing professionals. In order to better promote the training of horse racing talents, horse racing events should be guidance, and pay attention to the training of students' practice ability, event organization and implementation ability and information operation ability.

5.2 It is suggested that we should fully understand the market demand in the formulation process of the training and training programs of horse racing talents, listen to enterprises ' opinions, draw up talent training programs which are suitable for social development and demand for horse industry development, the orientation of the training programs should be based on horse racing events, pays attention to training talents' ability, and provide the talent guarantee for the rapid development of the horse industry in China.

\section{References}

[1]. Zou Jun, Look China's Horse Racing Supervision Institution Setting From the Characteristics of Commercial Horse Racing[J], Journal of Wuhan Commercial Service College, 2010 (3).

[2]. Lin Xiangjin, Liu Shaobo, Taking Horse Racing as a Leader to Change the Backwardness of Horse Breeding in China [J], Contemporary Animal Husbandry, 2004.7.

[3]. Liu Xinchun, Shi Xiaohan, Wen Wu, The Present Situation and Prospect of China'S Horse Industry[J], China Animal Husbandry Bulletin, 2008.9.

[4]. Chen Yanlun, Brief Discussion on the Training Direction of Hotel Management Specialty in Vocational School [J], Vocational Technology, 2008.8.

[5]. Xue Yajun, Find Training Direction of Compound Talents from the Internship [J], Journal of Jiamusi Education Institute, 2004.2.

[6]. Gu Dingqian, Thinking on the Direction of Talent Training in the Special Education Specialty in Colleges and Universities [J], Chinese Journal of Special Education, 2005.1

[7]. Ma Hongbo, Exploration and Practice of the Professionals' Training Direction of Chinese for Foreigners [J], Journal of Qiqihar University, 2010.7. 
[8]. Sun Jin, New Thinking of Training Direction of Professionals in Higher Vocational Hotel [J], Science \& Technology Information, 2008.7.

[9]. Qin Zunwen, To Issue Horseracing Lottery Will Be a Major Breakthrough in the Overall Development Of Urban And Rural Areas[J], Journal of Wuhan Commercial Service College, 2010 (5).

[10]. Yang Fenghua, Research on Influence of Horse Racing Culture on Horse Racing Industr [J], Journal of Wuhan Commercial Service College, 2010 (10).

[11]. Ding Peng, Analysis of the Influence of World Horse Racing Industry on China's Horse Racing Industry [J], Journal of Wuhan Commercial Service College 2010 (2).

[12]. Ding Peng, the Status of World Horse Racing and Prospects of China's Horse Racing [J], Modern Enterprise Education [J], 2010 (2). 